\title{
ASTER and field observations of the 24 December 2006 eruption of Bezymianny Volcano, Russia
}

\author{
Adam J. Carter ${ }^{\mathrm{a}, *}$, Olga Girina ${ }^{\mathrm{b}}$, Michael S. Ramsey ${ }^{\mathrm{a}}$, Yurii V. Demyanchuk ${ }^{\mathrm{b}}$ \\ ${ }^{a}$ Department of Geology and Planetary Science, University of Pittsburgh, Pittsburgh, PA 15260, USA \\ ${ }^{\mathrm{b}}$ Institute of Volcanology and Seismology (IVS), FED, RAS, Petropavlovsk-Kamchatsky, Russia
}

Received 9 October 2007; received in revised form 30 November 2007; accepted 2 December 2007

\begin{abstract}
An explosive eruption occurred at Bezymianny Volcano (Kamchatka Peninsula, Russia) on 24 December 2006 at 09:17 (UTC). Seismicity increased three weeks prior to the large eruption, which produced a $12-15 \mathrm{~km}$ above sea level (ASL) ash column. We present field observations from 27 December 2006 and 2 March 2007, combined with satellite data collected from 8 October 2006 to 11 April 2007 by the Advanced Spaceborne Thermal Emission and Reflection Radiometer (ASTER), as part of the instrument's rapid-response program to volcanic eruptions. Pixel-integrated brightness temperatures were calculated from both ASTER $90 \mathrm{~m} /$ pixel thermal infrared (TIR) data as well as $30 \mathrm{~m} / \mathrm{pixel}$ shortwave infrared (SWIR) data. Four days prior to the eruption, the maximum TIR temperature was $45^{\circ} \mathrm{C}$ above the average background temperature $\left(-33^{\circ} \mathrm{C}\right)$ at the dome, which we interpret was a precursory signal, and had dropped to $8{ }^{\circ} \mathrm{C}$ above background by 18 March 2007 . On 20 December 2006, there was also a clear thermal signal in the SWIR data of $128{ }^{\circ} \mathrm{C}$ using ASTER Band 7 (2.26 $\mu$ m). The maximum SWIR temperature was $181{ }^{\circ} \mathrm{C}$ on the lava dome on 4 January 2007, decreasing below the detection limit of the SWIR data by 11 April 2007 . On 4 January 2007 a hot linear feature was observed at the dome in the SWIR data, which produced a maximum temperature of $700{ }^{\circ} \mathrm{C}$ for the hot fraction of the pixel using the dual band technique. This suggests that magmatic temperatures were present at the dome at this time, consistent with the emplacement of a new lava lobe following the eruption. The eruption also produced a large, $6.5 \mathrm{~km}$ long by up to $425 \mathrm{~m}$ wide pyroclastic flow (PF) deposit that was channelled into a valley to the south-southeast. The PF deposit cooled over the following three months but remained elevated above the average background temperature. A second field investigation in March 2007 revealed a still-warm PF deposit that contained fumaroles. It was also observed that the upper dome morphology had changed in the past year, with a new lava lobe having in-filled the crater that formed following the 9 May 2006 eruption. These data provide further information on effusive and explosive activity at Bezymianny using quantitative remote sensing data and reinforced by field observations to assist in pre-eruption detection as well as post-eruption monitoring. (C) 2007 Elsevier Inc. All rights reserved.
\end{abstract}

Keywords: Bezymianny; Remote sensing; Thermal infrared; Monitoring; ASTER

\section{Introduction}

Bezymianny Volcano $\left(55.9^{\circ} \mathrm{N}, 160.6^{\circ} \mathrm{E}, \sim 2900 \mathrm{~m}\right.$ elevation) is located within the Klyuchevskaya volcanic group on the Kamchatka Peninsula in eastern Russia (Fig. 1. Bogoyavlenskaya et al., 1991). It erupted catastrophically in March 1956, collapsing to form a debris avalanche and directed blast deposit,

\footnotetext{
* Corresponding author. Department of Geology and Planetary Science, 200 SRCC Building, 4107 O'Hara St., University of Pittsburgh, Pittsburgh, PA 15260-3332, USA. Tel.: +1 412624 8780; fax: +1 4126243914 .

E-mail address: ajc44@pitt.edu (A.J. Carter).
}

which removed $0.5 \mathrm{~km}^{3}$ of material (Gorshkov 1959; Bogoyavlenskaya et al., 1985; Braitseva et al., 1991; Belousov, 1996; Belousov et al., 2007). This eruption created a summit crater that opens to the southeast and was the location of effusive activity that began to form Novy, the new summit lava dome (Bogoyavlenskaya et al., 1991). This style of activity, including a large lateral-blast eruption and subsequent crater infilling by lava dome growth, was later seen following the Mt. Saint Helens 1980 eruption and subsequent activity (Swanson et al., 1987; Anderson \& Fink, 1990; Vaughan et al., 2005).

Effusive dome growth at Bezymianny has continued for over fifty years since the formation of Novy, with the lava dome now 


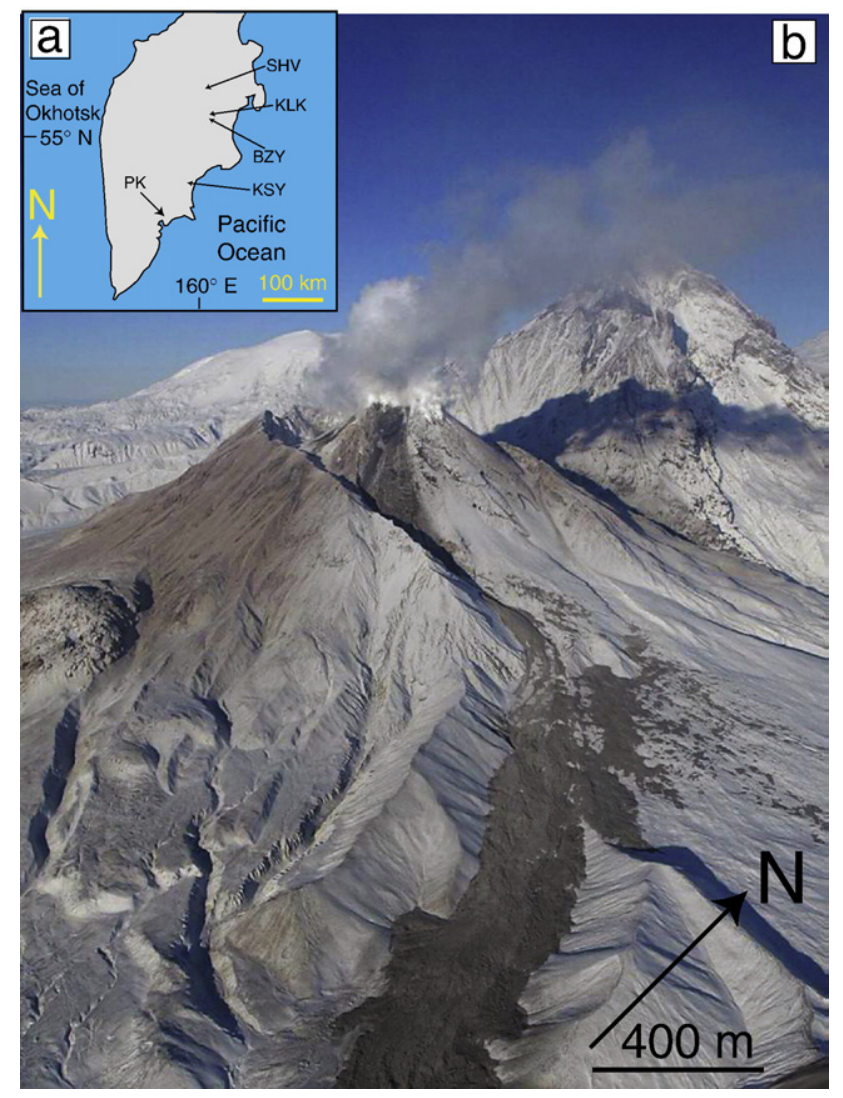

Fig. 1. (a) Geographic setting of the Kamchatka Peninsula, North Pacific Ocean. The main city of Petropavlovsk-Kamchatsky (PK) is indicated, as is the location of Sheveluch (SHV), Klyuchevskoy (KLK), Bezymianny (BZY), and Karymsky (KSY) volcanoes. (b) Aerial photograph taken 27 December 2006 looking northwest (Yu. Demyanchuk). Vigorous degassing was occurring at the summit, with dispersed ash observed on the south and west flanks (upper left of the image). In the foreground, part of the fresh pyroclastic flow deposit can be seen.

exceeding the height of the 1956 crater rim (Bogoyavlenskaya et al., 1991). By 1976, the dome had already grown to $0.36 \mathrm{~km}^{3}$ (Seleznev et al., 1984). Exogenous dome growth by short $(<1 \mathrm{~km})$ lava lobes is now the common style, with new material added to the dome surface. Lobe emplacement has been observed after several explosive eruptions (Belousov et al., 2002; Ramsey \& Dehn, 2004; Carter et al., 2007).

Explosive phases have also been noted at Bezymianny. Pyroclastic flow (PF) deposits have been concentrated, but not entirely restricted to, the south-eastern flank, channelled by the 1956 crater walls. Explosive eruptions occur one or two times a year on average, a pattern that has been observed over the past two decades (Belousov et al., 2002; Ramsey \& Dehn, 2004). The explosive phase commonly lasts several hours to days and is typically preceded by a crystalline spine (plug) that collapses to form rock avalanches (Belousov et al., 2002). The effusion of a lava flow or flows at the dome normally follows this phase several days to months after the explosion(s). PFs typically travel 4 to $7 \mathrm{~km}$ from the vent, with one recorded case (1985) of a PF travelling $12.5 \mathrm{~km}$ to the southeast (Belousov et al., 2002). In addition, lower bulk density pyroclastic surges have also been observed to travel off the main PF to not more than a few hundred metres away (Belousov et al., 2002).

Monitoring is conducted by the Kamchatka Volcanic Eruption Response Team (KVERT), the Institute of Volcanology and Seismology (IVS) Far East Division, Russian Academy of Sciences (FED RAS), the Kamchatkan Branch (KB) of Geophysical Surveys, Russian Academy of Sciences (GS RAS), and the Alaska Volcano Observatory (AVO), which is a joint program of the United States Geological Survey (USGS), the Geophysical Institute of the University of Alaska Fairbanks (UAFGI), and the State of Alaska Division of Geological and Geophysical Surveys (ADGGS). In addition, the University of Pittsburgh (UP) assists in observations through orbital data collection of data from the Advanced Spaceborne Thermal Emission and Reflection Radiometer (ASTER) sensor (Ramsey et al., 2004; Carter et al., 2007). The eruption described here as well as the recent high level of activity at Klyuchevskoy, Karymsky, and Sheveluch volcanoes demonstrates the need for continuous monitoring and information dissemination to interested groups (i.e., scientists, government agencies, and the aviation industry). This need does not originate from a direct danger to local populations, as there are very few inhabitants living close to the volcano. Rather, it is important for the mitigation of potential threats to aircraft from moderate to occasionally larger ash-emitting eruptions that penetrate the tropopause $\left(\sim 10-12 \mathrm{~km} \mathrm{ASL}\right.$ at $\left.55^{\circ} \mathrm{N}\right)$. Such activity may threaten many trans-Pacific routes of passenger and cargo jet aircraft from the United States to eastern Asia (Miller \& Casadevall, 2000).

Bezymianny has been selected as a test target for the ASTER sensor as part of a research investigation by the UP and AVO (Ramsey et al., 2004; Ramsey and Dehn, 2004; Carter et al., 2007). A previously-developed algorithm by AVO, which automatically processes thermal anomalies from low spatial resolution Advanced Very High Resolution Radiometer (AVHRR) data (Dehn et al., 2000), has been significantly improved allowing the triggering of an automatic urgent-priority ASTER image. These ASTER "rapid-response" datasets can commonly be scheduled and acquired within 1-5 days, and the data are available to the research team within $4 \mathrm{~h}$ of acquisition. This system does not have the ability to provide real-time data on an eruption, but does greatly improve the nominal ASTER scheduling/acquisition/ processing pathway, which is typically $1-2$ weeks long. Once acquired, the higher spatial and spectral resolution ASTER data can be of great value to scientists interested in assessing the posteruption state of the volcano (i.e., small-scale spatial, temporal, and thermal changes on lava domes and associated deposits). Since January 2000, 12 detected eruptions have coincided with the ASTER monitoring program (KVERT online report, 2007). Rapid-response ASTER data have been used to monitor the state of Bezymianny Volcano following the March 2000 eruption (Ramsey and Dehn, 2004), and together with limited field studies using the Forward Looking Infrared Radiometer (FLIR) thermal camera to successfully describe the 11 January 2005 eruption (Carter et al., 2007). We continue this work by analyzing field and satellite observations from the 24 December 2006 eruption and, in particular, investigate the emplacement of its deposits on the south-eastern flank. 


\section{Observation chronology and data}

\subsection{Local seismic observations and visual data}

The KB GS RAS observed that the seismic precursory phase of the 24 December 2006 explosive eruption began at the end of November, with the amount of near-surface volcanic earthquakes and their amplitudes increased gradually (Girina et al., 2006). From 9 December 2006, a series of low-frequency seismic events were registered almost daily, presumably linked to extrusive activity or rockfalls. The number of these events increased daily from 5 to 10 to 19 in the three days between 19 December and 21 December (KVERT report, 2006a). This increase in activity caused KVERT to change the colour code from yellow to orange at 20:30 UTC on 23 December. A prediction was issued, based on past experience from seismic evidence that an explosive eruption could occur between 23 and 31 December, possibly producing an eruption column of up to $15 \mathrm{~km}$ ASL (KVERT report, 2006b). According to webcam video data from Kozyrevsk village at a distance of $50 \mathrm{~km}$ to the west of Bezymianny, a large hot avalanche occurred at 23:52 UTC on 23 December, associated with an ash cloud that rose to $6 \mathrm{~km}$ ASL. At 02:40 UTC on 24 December the colour code for aviation hazards was again increased from orange to red (KVERT report, 2006c). Based on seismic data from the KB GS RAS, a strong explosive event began at 09:17 UTC (21:17 Kamchatka local time) on 24 December (KVERT report, 2006d). This message was sent at 11:10 UTC on 24 December by KVERT to aviation and scientific organizations in north Pacific region. The paroxysmal phase of eruption went on from 09:17 until 10:20 UTC on 24 December, with the volcanic tremor reaching $42.5 \mu \mathrm{m} / \mathrm{s}$. Visual data from a seismic station located in Kozyrevsk suggested that the eruption column rose to approximately $12-15 \mathrm{~km}$ ASL. The eruption reached its peak during the night, therefore the determination of the maximum column altitude was made using visible lightning flashes. On AVHRR and Moderate Resolution Imaging Spectroradiometer (MODIS) satellite images collected from 24 to 27 December, the ash cloud was observed to have gradually moved approximately $850 \mathrm{~km}$ northeast from the volcano. A report from the associates of F.Y. Lewinson-Lessing Kamchatkan Volcanological Station on 24 December in the town of Klyuchi stated that approximately $1 \mathrm{~cm}$ of ash from Bezymianny Volcano had settled on the ground (Fig. 2a). In addition, the observers noted that during the ash-fall there was a strong smell of sulphur.

Seismicity dropped to the background level at 22:00 UTC on 24 December, however, from 10:20 to 24:00 UTC on the same day there were approximately 30 (presumably hot) avalanches recorded. This was followed by only two events on 25 December. The colour code was lowered back to orange at 07:30 UTC on 25 December (KVERT report, 2006e) and then to yellow at 22:30 UTC on 28 December. A helicopter-based aerial survey was carried out by members of the KB GS RAS and KVERT on 27 December (Fig. 1b). It was observed that the southern slope of the dome was partially destroyed and a pyroclastic flow deposit was detected on the south-eastern slope of the volcano.

\subsection{ASTER data processing}

ASTER collects image-based data of reflected and emitted energy in the visible/near infrared (VNIR) region in three wavelength channels $(0.56-0.81 \mu \mathrm{m})$ at $15 \mathrm{~m} /$ pixel spatial
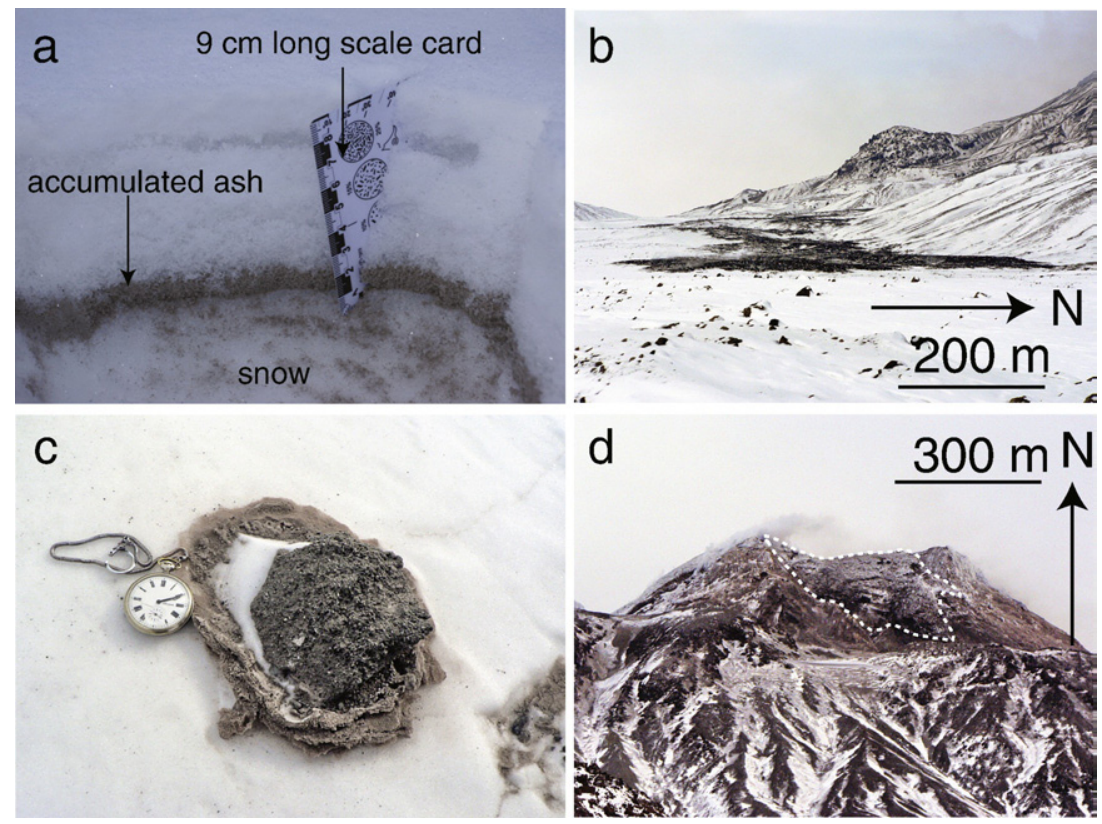

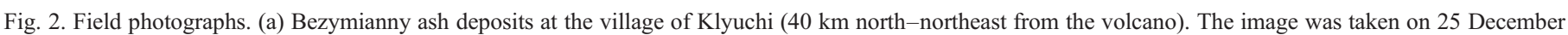

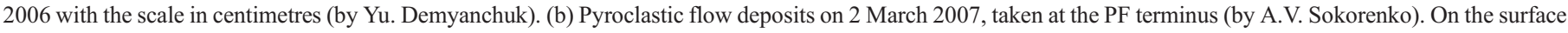

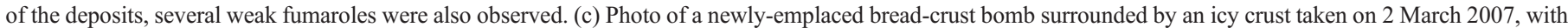

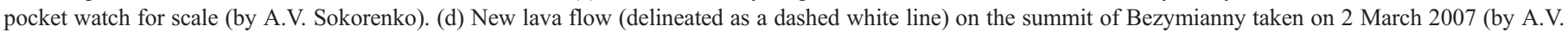
Sokorenko). The lava lobe continued to fill the southern part of the dome and over-spilled to the south. 
Table 1

ASTER TIR data used for this study, with all temperatures shown (in ${ }^{\circ} \mathrm{C}$ ) and derived using ASTER Level 2 AST-09T (TIR) data

\begin{tabular}{|c|c|c|c|c|c|c|}
\hline Date & ASTER granule ID & Day/night & Product & $T_{\mathrm{bg}}$ & Dome $T_{\max }$ & $\mathrm{PF} T_{\max }$ \\
\hline 8-Oct-2006 & AST_L1A.003:2037597787 & Night & L2 AST_09T & -12.22 & 17.28 & \\
\hline 27-Nov-2006 & AST_L1A.003:2038844472 & Night & L2 AST_09T & -23.47 & 19.96 & \\
\hline 20-Dec-2006 & AST_L1A.003:2039512095 & Night & L2 AST_09T & -33.76 & 45.06 & \\
\hline 4-Jan-2007 & AST_L1A.003:2039800277 & Day & L2 AST_09T & -33.44 & 34.62 & 18.26 \\
\hline 21-Jan-2007 & AST_L1A.003:2040146335 & Night & L2 AST_09T & -30.79 & $2.98^{*}$ & 22.31 \\
\hline $15-F e b-2007$ & AST_L1A.003:2040856230 & Night & L2 AST_09T & -28.11 & 25.28 & 14.91 \\
\hline 18-Mar-2007 & AST_L1A.003:2041808904 & Day & L2 AST_09T & -4.22 & 8.38 & 15.6 \\
\hline
\end{tabular}

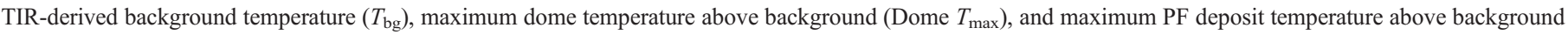
(PF $T_{\max }$ ) are shown. $\left(^{*}\right)$ denotes that on 21 January 2007 , clouds partially obscured the dome, generating a lower derived maximum temperature on this date.

resolution, in the SWIR region in six wavelength channels $(1.65-2.40 \mu \mathrm{m})$ at $30 \mathrm{~m} /$ pixel spatial resolution, and in the TIR region in five wavelength channels $(8.29-11.32 \mu \mathrm{m})$ at $90 \mathrm{~m} /$ pixel spatial resolution (Yamaguchi et al., 1998). These data are processed into various higher-level data products that range from geometrically and radiometrically corrected level 1 data (L1B) to level 2 (L2) data, which have been corrected for atmospheric radiance and sensor-specific errors (Abrams, 2000).

For this work, the L2 atmospherically corrected thermal radiance product (AST_09T) was used for the TIR analysis. TIR data have a lower sensitivity to higher surface temperatures where compared to SWIR data and lack the variable gain settings of the SWIR sensor. However, the TIR sensor has a much greater sensitivity to lower temperatures $\left(-73-97{ }^{\circ} \mathrm{C}\right)$ with a $1-2{ }^{\circ} \mathrm{C}$ detection threshold and $\pm 3 \mathrm{~K}$ radiometric accuracy (Yamaguchi et al., 1998). Thus the TIR can be used to monitor subtle thermal, compositional, and textural changes over time, especially after the dome and/or deposits have cooled below the detection threshold of the SWIR sensor (i.e., less than approximately $100{ }^{\circ} \mathrm{C}$ ). Seven ASTER TIR-derived temperature images were used to create a time series of thermal changes at Bezymianny (Table 1). All TIR data were extracted from the L2 radiance product and separated into temperature and emissivity using the emissivity normalization technique (Realmuto, 1990). The average background temperature for each image was calculated from a non-volcanic area of $50 \times 50$ TIR pixels $\left(\sim 20 \mathrm{~km}^{2}\right)$ at a similar elevation to the active dome. This value was used to derive the temperature at the volcano above the background.

For volcano studies, an advantage of the SWIR data other than its higher spatial resolution is the much higher detection limit for brightness temperatures, which is a function of the gain setting selected at the time of a scheduling as well as the SWIR wavelength examined. For example, at $2.40 \mu \mathrm{m}$ (band 9) the detectable brightness temperature range spans from $86{ }^{\circ} \mathrm{C}-$ $329^{\circ} \mathrm{C}$ (high gain versus low gain 2 ), whereas at $1.65 \mu \mathrm{m}$ (band 4) the range for the same gain settings increases to $250{ }^{\circ} \mathrm{C}-$ $467{ }^{\circ} \mathrm{C}$ (Urai et al., 1999). This can be useful where distinguishing volcanic features such as high temperature fumaroles, lava flows, and PF emplacement. For the SWIR analysis, either L1B data (night-time acquisitions) or L2 atmospherically and cross-talk corrected (AST_09XT) data (daytime acquisitions) were used. The higher-level data products for ASTER SWIR were originally derived by the ASTER science team for daytime scenes only and therefore not available for night-time SWIR data. As the sun contributes a small fraction of reflected energy to the surface, it becomes averaged together with the energy emitted from the hot surfaces. Therefore, this solar reflected component was removed for all daytime data prior to extracting the temperature. Similar to the calculation for the average TIR background temperature, the radiance from a $\sim 20 \mathrm{~km}^{2}$ non-active region of similar albedo, shadowing, and elevation to the dome was selected and the solar reflected component was subtracted from the thermally-elevated SWIR pixels. ASTER SWIR data were acquired on four dates from 20 December 2006 to 11 April 2007 (Table 2). The pixel-integrated brightness temperature was extracted from the $2.26 \mu \mathrm{m}$ band (SWIR band 7) using the reference channel approach (Kahle, 1987). For this approach, a maximum emissivity is assumed and assigned to one wavelength, thus allowing the Planck equation to be solved for the temperature.

\subsection{Pre-eruption satellite observations}

Following the first thermal anomaly detected by the AVHRR sensor, ASTER was scheduled in rapid-response mode to collect data, which it continued to do over the following 3 months

Table 2

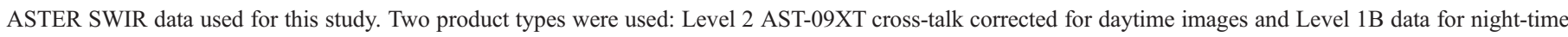
images (where the AST_09XT product was not available)

\begin{tabular}{|c|c|c|c|c|}
\hline Date & ASTER granule ID & Day/night & Product & Dome $T_{\max }$ \\
\hline 20-Dec-2006 & AST_L1A.003:2039512095 & Night & Level 1B & 128 \\
\hline 4-Jan-2007 & AST_L1A.003:2039800277 & Day & Level 2 AST_09XT & 181 \\
\hline 18-Mar-2007 & AST_L1A.003:2041808904 & Day & Level 2 AST_09XT & 180 \\
\hline 11-Apr-2007 & AST_L1A.003:2042182677 & Night & Level 1B & $*$ \\
\hline
\end{tabular}

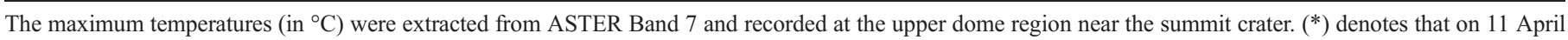
2007, the temperature was below the detection threshold of the SWIR sensor at this wavelength. 


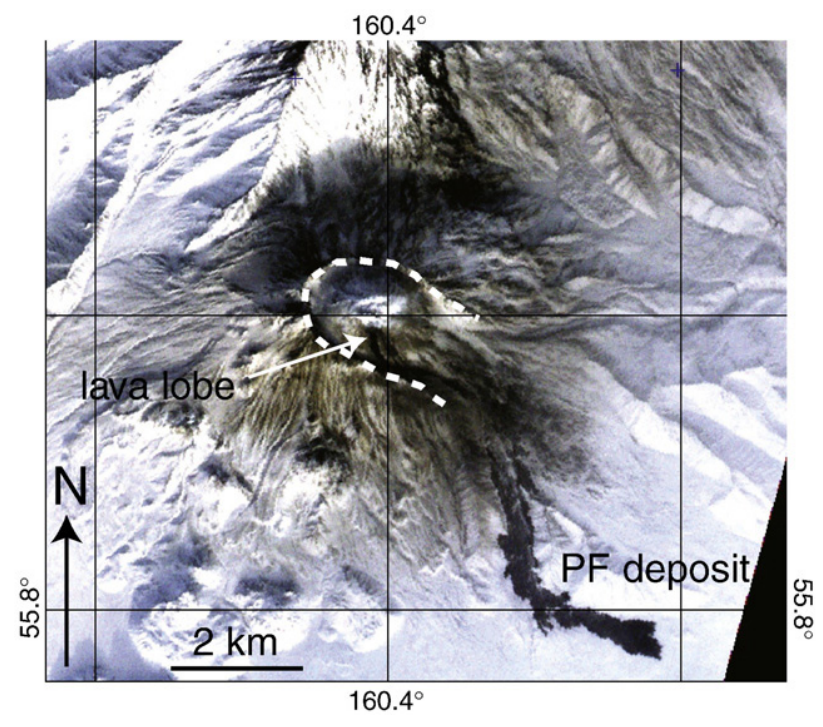

Fig. 3. ASTER VNIR image of Bezymianny from 4 January 2007. Coordinates are given in latitude/longitude. The 1956 crater is highlighted with a white dashed line. At the dome summit a dark, linear feature was observed on the upper part of the southeast face of the dome. In addition, the $6.5 \mathrm{~km}$ long fresh pyroclastic flow can be seen to the southeast of the summit in a connecting valley.

(Tables 1 and 2). Prior to the eruption, three night-time images were acquired on 8 October, 27 November, and 20 December 2006, with TIR brightness temperatures of $17{ }^{\circ} \mathrm{C}, 20^{\circ} \mathrm{C}$, and $45^{\circ} \mathrm{C}$, respectively. On 20 December, much of the surface of the dome was thermally-elevated above the background, with $526,500 \mathrm{~m}^{2}$ (65 pixels) more than $10^{\circ} \mathrm{C}, 48,600 \mathrm{~m}^{2}$ (6 pixels) more than $20{ }^{\circ} \mathrm{C}, 32,400 \mathrm{~m}^{2}$ (4 pixels) more than $30{ }^{\circ} \mathrm{C}$, and $8100 \mathrm{~m}^{2}$ ( 1 pixel) more than $40{ }^{\circ} \mathrm{C}$. Over the same area, the maximum SWIR-derived brightness temperature was $128{ }^{\circ} \mathrm{C}$, however the higher spatial resolution of SWIR allowed for much better discrimination and location of the thermal anomalies.

The persistently active degassing and low temperature emission from Bezymianny's dome commonly produces thermallyelevated TIR pixels in ASTER data. However, only during times of eruption with a dramatic temperature increase in the fumaroles and/or the emplacement of new lava flows on the surface of the dome are elevated SWIR radiance values detected. Therefore, we interpret the elevated SWIR temperatures and the rapid increase in TIR temperature on 20 December 2006 to be an indication of precursory high temperature fumarole activity or the extrusion of a lava spine.

\subsection{Post-eruption satellite observations}

The next ASTER scene was a daytime VNIR-SWIR-TIR image, collected on 4 January 2007, 11 days after the eruption (Figs. 3 and 4). Dispersed fine ash covered the flanks of the volcano discolouring the snow and a steam plume was concentrated over the central dome. A low-albedo, narrow feature was noted leading from the central craters down slope on the southeast flank of the dome (Fig. 3). This also coincided with the warmest ASTER TIR pixel on that date $\left(35^{\circ} \mathrm{C}\right.$ above background). Twelve ASTER TIR pixels, corresponding to an area of $97,200 \mathrm{~m}^{2}$, were more than $10^{\circ} \mathrm{C}$ above background in this area.

Also observed in the ASTER VNIR data was a large lowalbedo PF deposit approximately $6.5 \mathrm{~km}$ in length and up to $425 \mathrm{~m}$ in width, which travelled from the south portion of the dome and into the south-southeast branching valley. The PF deposit filled the width of the upper valley and contained several lobes that diverged from the main flow. At a distance of $5 \mathrm{~km}$ from the vent, the flow was redirected approximately $90^{\circ}$ to the east-southeast (Fig. 4b). The total PF deposit areas that were $10{ }^{\circ} \mathrm{C}$ and $15^{\circ} \mathrm{C}$ above the TIR background temperature were $2.04 \mathrm{~km}^{2}$ and $0.17 \mathrm{~km}^{2}$, respectively. The maximum recorded surface temperature above background was $18{ }^{\circ} \mathrm{C}$, located at the terminus of the deposit and $15{ }^{\circ} \mathrm{C}$ above background where the PF was redirected from the south to the eastsoutheast. However, all areas of the PF that were greater than $15^{\circ} \mathrm{C}$ above background were found over $4.5 \mathrm{~km}$ from the central dome region.

TIR emissivity spectra of the deposit had a noted negative slope at wavelengths longer than $10 \mu \mathrm{m}$ (bands 13 and 14), suggesting that sub-pixel temperature mixing is occurring within the $90 \mathrm{~m}$ pixels (Ramsey \& Kuhn, 2004). This may be due to multiple surface components such as surface snow, fine ash, and larger blocks all radiating at different temperatures. The night-time image from 21 January 2007 contained a very weak thermal anomaly on the dome, possibly due to clouds obscuring the surface. However, the entire newly-emplaced PF deposit

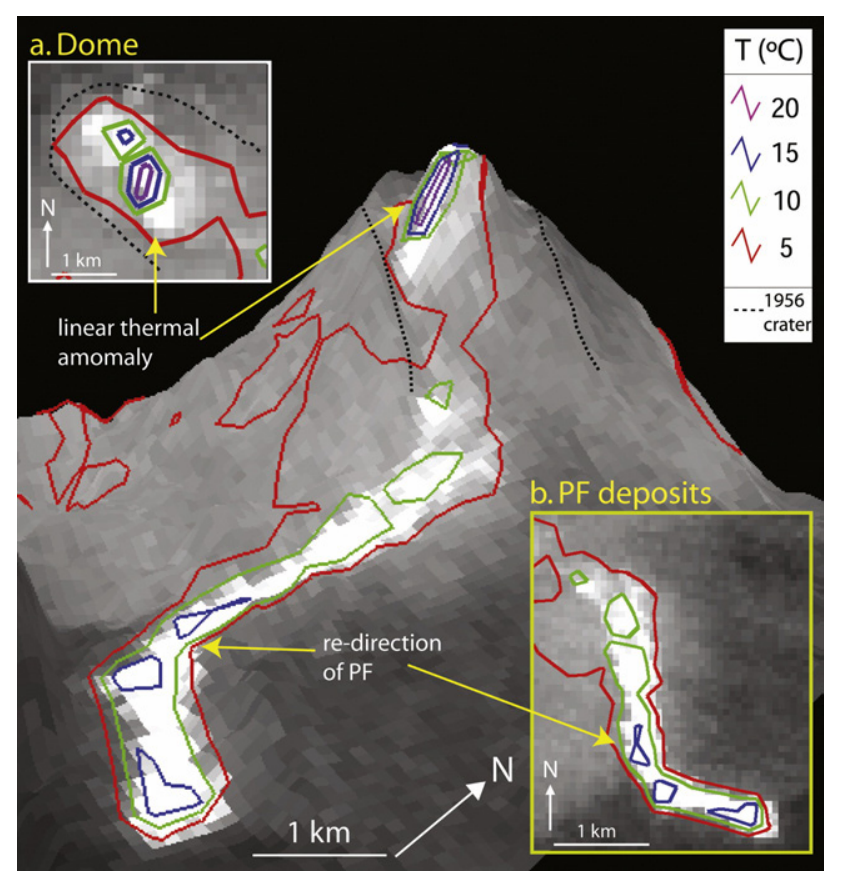

Fig. 4. ASTER TIR data from 4 January 2007 draped on an ASTER-derived Digital Elevation Model (DEM) from 18 March 2007 with $3 \times$ vertical exaggeration. Temperature contours are ${ }^{\circ} \mathrm{C}$ above background. (a) Dome region in plan-view showing a SE-NW trending warm region extending from the centre of the dome, which is the location of the new lava lobe. Maximum SWIRderived temperatures were $181^{\circ} \mathrm{C}$ in this area on the same date. (b) Main deposit region in plan-view showing warmest regions in the area where the deposit was redirected to the east-southeast and the deposit terminus (blue contours). 
remained elevated approximately $10{ }^{\circ} \mathrm{C}$ above background, with the warmest being $22{ }^{\circ} \mathrm{C}$ (above a background of $-31^{\circ} \mathrm{C}$ ). This pixel was located within the central part of the deposit where the flow became redirected towards the east-southeast (Fig. 4). After emplacement of the PF deposit, the maximum recorded temperature increased slightly from $18{ }^{\circ} \mathrm{C}$ to $22{ }^{\circ} \mathrm{C}$ between 4 January and 21 January. This minor change is close to the accuracy of the TIR data and could be due to either incomplete atmospheric correction, for example, or increased emitted heat from large buried blocks with higher thermal inertia values. Following this, the maximum PF temperature stabilised at $15{ }^{\circ} \mathrm{C}$ above background during February and March. During the study period, the background temperature increased from $-33{ }^{\circ} \mathrm{C}$ to $-4{ }^{\circ} \mathrm{C}$ due to seasonal effects. However, between 15 February and 18 March, the temperature above background for the deposit remained stable. This suggests that the deposit cooled as the background temperature

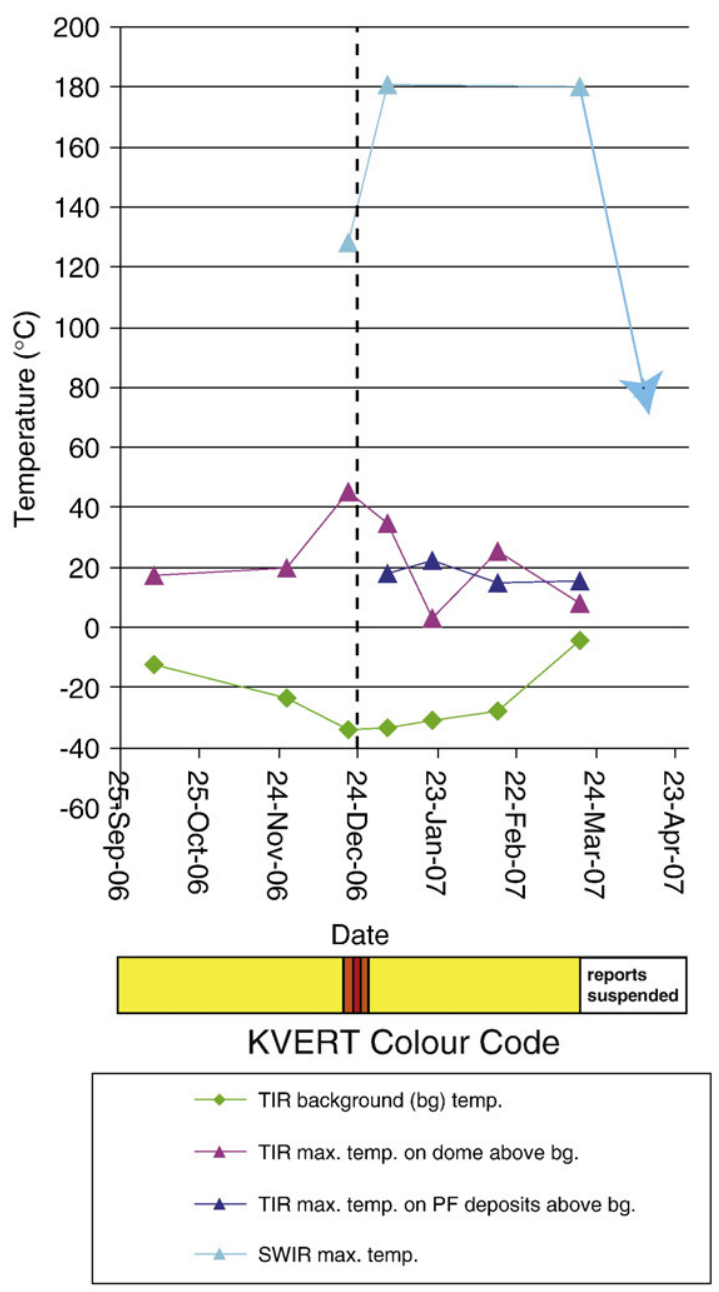

Fig. 5. ASTER-derived TIR temperatures (T) in ${ }^{\circ} \mathrm{C}$ for the average background (green), the maximum temperature on the lava dome (pink), and the maximum temperature on the PF deposit (blue) shown from 20 December 2006 to 18 March 2007 (displayed as day/month/year). The start of the eruption on 24 December 2006 (marked as a dashed vertical line) is indicated. SWIR temperatures are also shown from 20 December 2006 to 11 April 2007 (turquoise). KVERT colour codes are displayed below the graph. increased from $-28{ }^{\circ} \mathrm{C}$ to $-4{ }^{\circ} \mathrm{C}$. During the entire study period, no SWIR thermal anomalies were recorded over the PF deposit region, suggesting that surface temperatures had cooled below, or had never reached, the detectable range for the SWIR data.

\subsection{Time series of ASTER-derived temperatures}

TIR data of the lava dome showed a gradual reduction in the maximum temperature above background from $45^{\circ} \mathrm{C}$ to $8{ }^{\circ} \mathrm{C}$ over the December 2006-March 2007 time period (Fig. 5, Table 1). However, the SWIR-derived temperature increased from $128^{\circ} \mathrm{C}$ on 20 December 2006 to $181^{\circ} \mathrm{C}$ on 4 January 2007 (Fig. 5, Table 2). This likely indicates either an increase in the thermal flux from fumaroles and/or the presence of high temperature cracks in the newly extruded lobe on the dome. By 11 April 2007, the SWIR temperature decreased to below the detection limit, indicating that surface magmatic activity had also decreased at this time.

One disadvantage of using only the maximum temperature in a remote sensing data set to describe the volcanic activity is that the areal influence of warm pixels is ignored. For example, on 20 December 2006 several thermally-elevated SWIR pixels were within the spatial footprint of one thermally-elevated TIR pixel. Therefore, direct comparison of ASTER TIR and SWIR temperatures is challenging and requires modelling of thermal data to estimate the warm fraction of the pixel that may be producing the thermal signal.

The hottest $30 \mathrm{~m}$ SWIR pixel on the dome $\left(181^{\circ} \mathrm{C}\right)$ on 4 January 2007 was subjected to the dual band method of subpixel temperature extraction (Dozier, 1981; Matson \& Dozier, 1981; Rothery et al. 1988; Harris et al., 1997; Ramsey and Dehn, 2004). This simple methodology assumes that for the thermally-elevated pixel there are two radiant temperatures present at the surface: a cooler background and a warmer volcanic temperature (e.g. lava flow, PF deposits, or gas/steam, for example). Also assumed is a linear relationship between the ratio of hot to cool fractions of the pixel and the ratio of the hot and cold components of the total radiance. If an assumption is made for the emissivity of the pixel's surface at two wavelengths, then there will remain three unknowns: the hot and cold temperatures and the areal fraction of hot temperature. With two equations and three unknowns, a further assumption (e.g., the temperature of the hot fraction or the area of the hot fraction) is made and the remaining unknowns can be solved.

Using corrected SWIR radiance values at $1.656 \mu \mathrm{m}$ and $2.4 \mu \mathrm{m}$ (bands 4 and 9, respectively) and an assumed background temperature of $0{ }^{\circ} \mathrm{C}$, the mathematically-feasible temperature range for the hot fraction can be solved. The high accuracy of the SWIR data leads to the possibility of detection for an area as small as $0.001 \%\left(\sim 1 \mathrm{~m}^{2}\right)$ of the $30 \mathrm{~m}$ pixel. This assumption produces a range of temperatures from 300 to $700{ }^{\circ} \mathrm{C}$ for the hot fraction. If this hot fraction is increased to $0.011 \%\left(10 \mathrm{~m}^{2}\right)$, the range of hot temperatures is decreased $\left(180{ }^{\circ} \mathrm{C}\right.$ to $\left.500{ }^{\circ} \mathrm{C}\right)$. Based on the range of plausible temperatures and direct field-based FLIR observations of the lava lobes at the dome in 2004 and 2005, it is unlikely that fumarolic activity was responsible for the SWIR anomalies on the 4 
January 2007. Surface lava temperatures were most likely responsible, which is consistent with a short lobe being emplaced at the summit. Clearly, the two temperature model is simplified as demonstrated by Wright and Flynn (2003). A multiple component (up to the number of ASTER SWIR bands) calculation could also be carried out to further refine the number and temperature of several different thermal anomalies. However, this level of detail is beyond the scope of this study, which sought only to discriminate between high temperature fumarolic activity and lava on the surface.

\subsection{March 2007 field observations}

IVS FED and KB GS RAS scientists revisited the volcano on 2-3 March 2007 and observed that the PF deposits were almost snow-free, despite the low atmospheric temperatures (Fig. 2b). On the surface of the deposits, a few weak fumaroles were also observed. Fresh volcanic bread-crust bombs surrounded by an icy crust were found approximately $2.5 \mathrm{~km}$ from the pass separating Bezymianny and Kamen (Fig. 2c). This ice rind was formed as the hot bombs fell on snow, causing rapid melting and refreezing. It was also observed that the central dome craters initially formed on 9 May 2006 were now filled with lava. The lava lobe continued to fill the southern part of the dome and over-spilled to the south (see Fig. 2d).

\section{Discussion}

The derived above background brightness temperatures for the dome of $45^{\circ} \mathrm{C}$ and $128{ }^{\circ} \mathrm{C}$ (TIR and SWIR, respectively), relative to lower temperatures observed in October and November 2006, clearly indicate that activity was considerably elevated on 20 December 2006. High temperatures were present at the dome surface four days prior to the eruption, possibly due to vigorous degassing, or the emplacement of a lava spine (Belousov et al., 2002). On 4 January 2007, 11 days after the eruption, a thermally-elevated SWIR region was observed at the dome. Based on modelling using the dual band technique, we demonstrate how this may have been caused by a small fraction of the pixel emitting at magmatic temperatures. Visual observations at Bezymianny on 2 March 2007 by IVS/KB GS RAS scientists later confirmed the presence of a viscous lava lobe emplaced on the southern portion of the upper dome in the location of the thermally-elevated SWIR pixel (Fig. 2d).

A PF was concentrated within the south-southeast branching valley and emplaced over fresh snow to produce a distinct colour contrast (Fig. 3). Lower temperatures of the deposit were recorded near to the dome where the high slopes prevented the accumulation of material, relative to the area lower down to the southeast. The thickest deposits occurred on the lower, less steep slopes. Two areas of interest were identified using satellite and ground-based data: 1) the region where the PF was redirected to the east-southeast; and 2) the terminus of the flow deposit (Fig. 4). Data from 4 January 2007 showed the first area was warmer on average $\left(15^{\circ} \mathrm{C}\right.$ above background) than the rest of the deposit, except for the PF terminus $\left(18{ }^{\circ} \mathrm{C}\right.$ above background. See Fig. 4b). If a levee was formed where the flow changed direction and decelerated, the larger and denser blocks would have been deposited. These blocks would likely retain heat longer due to their higher thermal inertia. The granular flow would also likely form a thicker terminus on the lower slopes, which would also retain heat longer. Later field observations confirmed the terminus was $\sim 1.5 \mathrm{~m}$ thick and contained a higher concentration of blocks. Furthermore, the pixel temperatures of this region remained elevated for 2-3 months after the eruption. The pixel directly down slope of the terminus remained at the background temperature, which implies the flow did not spread diffusely as it came to rest, further validating using solely remote sensing methods, that the deposit was a thicker, coherent block and ash flow-type PF rather than a pyroclastic surge.

\section{Conclusions}

Based on seismic and field-based observations, an explosive eruption occurred at Bezymianny from 09:17 until 10:20 UTC on 24 December (21:17 to 22:20 local time), generating an ash cloud estimated to be $12-15 \mathrm{~km}$ in height. Four days prior to the eruption a distinct increase in TIR temperatures was noted in combination with a signal from SWIR data, indicating higher temperatures at the dome. We interpret that this provided a precursory signal prior to the large eruption.

Following the eruption, modelling of SWIR data from 4 January 2007 showed that a small fraction $\left(\sim 1 \mathrm{~m}^{2}\right)$ of a SWIR pixel on the dome could have contained temperatures ranging from $300{ }^{\circ} \mathrm{C}$ to $700{ }^{\circ} \mathrm{C}$. Even if the area was as large as $10 \mathrm{~m}^{2}$, the hot fraction would range from $180{ }^{\circ} \mathrm{C}$ to $500{ }^{\circ} \mathrm{C}$, suggesting the thermal activity was caused by hot cracks in a lava lobe surface and not fumaroles. Field observations in March 2007 confirmed the presence of the still-warm PF deposit and a new summit lava lobe that in-filled the 9 May 2006 crater, in accordance with ASTER observations. A large, $6.5 \mathrm{~km}$ long PF deposit was emplaced on the southeast flank of the volcano, concentrated in the south-southeast branching valley, and remained at elevated temperatures for over 4 months. The warmest areas on the deposit corresponded to regions where a block-rich natural levee occurred during a change in flow direction as well as at the terminus, which was thicker than the main body of the deposit. This was caused by an increased concentration of blocks with higher thermal inertia values, thereby keeping the temperatures elevated. These observations were derived using ASTER SWIR and TIR products and later confirmed by field observations.

ASTER day- and night-time observations were used to supplement local monitoring data. The December 2006 eruption occurred in a remote location of Russia at $-30{ }^{\circ} \mathrm{C}$ atmospheric temperature and in near-total darkness, negating the possibility of visual observations until after the deposit was formed. To compliment this data set, a thermal infrared study using FLIR data was carried out in August 2007 and will be incorporated in to future work to calibrate derived temperatures with spaceborne data over the dome and particularly the warm PF deposits. ASTER is the only high spatial resolution, multispectral TIR imaging system available for this style of detailed thermal 
volcanic studies and monitoring and is adding to a global volcanic archive of thermal data for similar future studies.

\section{Acknowledgements}

This work was funded by the NASA ASTER Science Team (NNG04GO69G) (MSR), the Andrew W. Mellon Foundation (AJC), and the Henry Leighton Memorial Scholarship (AJC). Many thanks to Evgenii Gordeev and Oxana Evdokimova at the IVS FED RAS for continued logistical support and Alexander V. Sokorenko at the IVS FED RAS for field photographs, AVO members Rick Wessels and Jon Dehn for continued support with the rapid-response, north Pacific volcanism program. AJC personally thanks Vladislav Kaminsky at the University of Pittsburgh for kindly assisting with the Russian-English translation, Nerissa and Linda Lindenfelser for edits, and Andrea Steffke for thermal modelling advice. This work has been greatly improved by the detailed reviews of Jon Dehn and three other anonymous reviewers.

\section{References}

Abrams, M. (2000). The Advanced Spaceborne Thermal Emission and Reflectance Radiometer (ASTER): data products for the high spatial resolution imager on NASA's Terra platform. International Journal of Remote Sensing, 21, 847-859.

Anderson, S. W., \& Fink, J. H. (1990). The development and distribution of lava textures at the Mount St. Helens dome. In J. H. Fink (Ed.), Lava flows and domes: Emplacement mechanisms and hazard implications, Vol. 2 (pp. 25-46). Berlin: Springer

Belousov, A. B. (1996). Deposits of the 30 March 1956 directed blast at Bezymianny Volcano, Kamchatka, Russia. Bulletin of Volcanology, 57, 649-662.

Belousov, A., Voight, B., Belousova, M., \& Petukhin, A. (2002). Pyroclastic surges and flows from the 8-10 May 1997 explosive eruption of Bezymianny Volcano, Kamchatka, Russia. Bulletin of Volcanology, 64, 455-471.

Belousov, A. B., Voight, B., \& Belousova, M. (2007). Directed blasts and blastgenerated pyroclastic density currents: a comparison of the Bezymianny 1956, Mount Saint Helens 1980, and Soufrière Hills, Montserrat 1997 eruptions and deposits. Bulletin of Volcanology, 69, 701-740.

Bogoyavlenskaya, G. E., Braitseva, O. A., Melekestsev, I. V., Kirianov, V. Yu., \& Miller, D. (1985). Catastrophic eruptions of the directed blast type at Mount St. Helens, Bezymyanny and Shiveluch volcanoes. Journal of Geodynamics, 3, 189-218.

Bogoyavlenskaya, G. E., Braitseva, O. A., Melekestsev, I. V., Maksimov, A. P., \& Ivanov, B. V. (1991). Bezymianny Volcano. In S. A. Fedotov, \& Yu. P. Masurenkov (Eds.), Active volcanoes of Kamchatka, Vol. 1 (pp. 195-197). Moscow: Nauka.

Braitseva, O. A., Melekestsev, I. V., Bogoyavlenskaya, G. E., \& Maksimov, A. P. (1991). Bezymyannyi: Eruptive history and dynamics. Volcanology and Seismology, 12, 165-194.

Carter, A. J., Ramsey, M. S., \& Belousov, A. B. (2007). Detection of a new summit crater on Bezymianny Volcano lava dome: satellite and field-based thermal data. Bulletin of Volcanology, 69, 811-815.

Dehn, J., Dean, K. G., \& Engle, K. (2000). Thermal monitoring of North Pacific volcanoes from Space. Geology, 28, 755-758.

Dozier, J. (1981). A method for satellite identification of surface temperature fields of subpixel resolution. Remote sensing of Environment, 11, 221-229.

Girina, O. A., Senyukov, S. L., Malik, N. A., Manevich, A. G., Ushakov, S. V., Mel'nikov, D. V., et al. (2006). Activity of Kamchatkan and Northern Kuriles (Paramushir Island) volcanoes, Vestnik KRAUNC. Sciences of the Earth, Vol. 2, 151-157. http://www.kscnet.ru/kraesc/2006/2006_8/art13.pdf
Gorshkov, G. S. (1959). Gigantic eruption of the Bezymianny Volcano. Bulletin of Volcanology, 20, 77-109.

Harris, A. J. L., Butterworth, A. L., Carlton, R. W., Downey, I., Miller, P., Navarro, P., et al. (1997). Low-cost volcano surveillance from space: case studies from Etna, Krafla, Cerro Negro, Fogo, Lascar and Erebus. Bulletin of Volcanology, 59, 49-64.

Kahle, A. B. (1987). Surface emittance, temperature, and thermal inertia derived from thermal infrared multi-spectral scanner (TIMS) data for Death Valley, California. Geophysics, 52, 858-874.

Kamchatka Volcanic Eruption Response Team (KVERT) Report (2006a). Bezymianny Volcano. 21 December 2006 UTC (http://www.avo.alaska.edu/ activity/avoreport.php?view $=$ kaminfo \&id=210\&type $=$ kaminfo\&month= December\&year=2006).

Kamchatka Volcanic Eruption Response Team (KVERT) Report (2006b). Bezymianny Volcano. 23 December 2006 UTC (http://www.avo.alaska.edu/ activity/avoreport.php?view $=$ kaminfo\&id= $211 \&$ type $=$ kaminfo \&month $=$ December\&year=2006).

Kamchatka Volcanic Eruption Response Team (KVERT) Report (2006c). Bezymianny Volcano. 24 December 2006 UTC (http://www.avo.alaska.edu/ activity/avoreport.php?view=kaminfo\&id=212\&type=kaminfo\&month= December\&year=2006).

Kamchatka Volcanic Eruption Response Team (KVERT) Report (2006d). Bezymianny Volcano. 24 December 2006 UTC (http://www.avo.alaska.edu/ activity/avoreport.php?view $=$ kaminfo\&id $=213 \&$ type $=$ kaminfo\&month $=$ December\&year=2006).

Kamchatka Volcanic Eruption Response Team (KVERT) Report (2006e). Bezymianny Volcano. 25 December 2006 UTC (http://www.avo.alaska.edu/ activity/avoreport.php?view=kaminfo\&id=214\&type=kaminfo\&month= December\&year=2006).

Kamchatka Volcanic Eruption Response Team (KVERT) On line Report (2007). (http://www.kscnet.ru/ivs/kvert/volcanoes/Bezymianny/index_eng.html).

Matson, M., \& Dozier, J. (1981). Identification of subresolution high temperature sources using a thermal IR sensor. Photogrammetric Engineering and Remote Sensing, 47, 1311-1318.

Miller, T. P., \& Casadevall, T. J. (2000). Volcanic ash hazards to aviation. In H. Sigurdsson, B. F. Houghton, S. McNutt, H. Rymer, \& J. Stix (Eds.), Encyclopedia of volcanoes (pp. 915-930). San Diego, CA: Academic Press.

Ramsey, M. S., \& Kuhn, S. (2004). Fusion of parametric and thematic data to characterize the Soufrière Hills volcanic dome. Abstracts of the General. Assembly: IAVCEI.

Ramsey, M. S., Dehn, J., Wessels, R., Byrnes, J., Duda, K., Maldonado, L., et al (2004). The ASTER emergency scheduling system: A new project linking near-real-time satellite monitoring of disasters to the acquisition of highresolution remote sensing data. American Geophysical Union Fall Meeting (abs. SF23A-0026).

Ramsey, M. S., \& Dehn, J. (2004). Spaceborne observations of the 2000 Bezymianny, Kamchatka eruption: The integration of high-resolution ASTER data into near real-time monitoring using AVHRR. Journal of Volcanology and Geothermal Research, 135, 127-146.

Realmuto, V. J. (1990). Separating the effects of temperature and emissivity: Emissivity spectrum normalization. In E. A. Abbott (Ed.), Proceedings of the second thermal infrared multispectral scanner (TIMS) workshop Pasadena, CA: Jet Propulsion Laboratory.

Rothery, D. A., Francis, P. W., \& Wood, C. A. (1988). Volcano monitoring using short wavelength infrared data from satellites. Journal of Geophysical Research, 93, 7993-8008

Seleznev, B. V., Dvigalo, V. N., \& Gusev, N. A. (1984). Evolution of Bezymianny Volcano from stereoscopic plotting of aerial photographs of 1950, 1967, 1976-1981. Volcanology and Seismology, 5, 53-66.

Swanson, D. A., Dzurisin, D., Holocomb, R. T., Iwatsubo, E. Y., Chadwick, W. W., Jr., Casadevall, T. J., et al. (1987). Growth of the lava dome at Mount Saint Helens, Washington (USA), 1981-1983. In J. H. Fink (Ed.), The emplacement of silicic lava domes and lava flows. Special Paper for the Geological Society of America, Vol. 12 (pp. 1-16).

Urai, M., Fukui, K., Yamaguchi, Y., \& Pieri, D. C. (1999). Volcano observation potential and global volcano monitoring plan with ASTER. Bulletin of the Volcanological Society of Japan, 44, 131-141. 
Vaughan, R. G., Hook, S. J., Ramsey, M. S., Realmuto, V. J., \& Schneider, D. J. (2005). Monitoring eruptive activity at Mount Saint Helens with TIR image data. Geophysical Research Letters, 32, L19305. doi:10.1029/2005GL024112 Wright, R., \& Flynn, L. (2003). On the retrieval of lava-flow surface temperatures from infrared satellite data. Geology, 31, 893-896.
Yamaguchi, Y., Kahle, A. B., Tsu, H., Kawakami, T., \& Pniel, M. (1998). Overview of Advanced Spaceborne Thermal Emission and Reflection Radiometer (ASTER). IEEE Transactions on Geoscience and Remote Sensing, 36, 1062-1071. 